\title{
Anti-inflammatory role of papaya seed extracts in inhibiting osteoclastogenesis of rats with Periodontitis
}

\author{
Ratih Pusporini*, Ahmad Basorii*, Agung Krismariono*** \\ *Department of Oral Biology, Faculty of Dentistry, Universitas Brawijaya, Malang, East Java, Indonesia \\ **Department of Pharmacology, Faculty of Medicine, Universitas Airlangga, Surabaya, East Java, Indonesia \\ ${ }^{* * *}$ Department of Periodontics, Faculty of Dentistry, Universitas Airlangga, Surabaya, East Java, Indonesia \\ *JI Veteran, Malang, East Java, Indonesia; e-mail: ratih.fk@ub.ac.id
}

Submitted: 21 ${ }^{\text {st }}$ July 2017; Revised: $30^{\text {th }}$ October 2017; Accepted: 20 ${ }^{\text {nd }}$ November 2017

\begin{abstract}
Some previous studies mentioned that papaya seed extract has anti-inflammatory activity because it contains polyphenols including phenolic and flavonoid acids. Polyphenols of the papaya seed extracts are known to inhibit the severity of periodontitis. It can prevent the release of excessive osteoclastogenesis which may promote bone resorption aggravating periodontitis. Hence, this study aims to determine the role of papaya seed extract in reducing the number of osteoclasts in rats with periodontitis. Twenty-eight male Wistar rats were divided into 4 groups of induced periodontitis using lipopolisakarida (LPS) Porphyromonas gingivalis (P. Gingivalis) and followed by wire ligature in " 8 " placed around the mandible mandibular incisor. The first group was given standard food without any papaya extract, while each rat in three other groups with periodontitis (P2, P3, P4) was given with Papaya seed extracts of $200 \mathrm{mg} / \mathrm{kgBW}, 300 \mathrm{mg} / \mathrm{kgBW}$, and $400 \mathrm{mg} / \mathrm{kgBW}$. Seven rats in one group were not induced by periodontitis and were fed with standard food as a control group. On the 30th day, the rat was sacrificed, and its transverse pieces of alveolar bone around the mandibular incisor were stained with Hematoxylin-Eosin. The data analyzed by one way ANOVA indicated a significant result. Thus, it is conclusive that extract of papaya seed ethanol inhibited osteoclastogenesis in Wistar rats induced with periodontitis.
\end{abstract}

Keywords: flavonoid; osteoclast; papaya seed extract; phenolic acid; periodontitis

\section{INTRODUCTION}

Periodontitis is a chronic infectious disease in periodontal tissue due to the accumulation of sub gingival microbial pathogens. Consequently, these accumulated microbial pathogens will trigger an immune response destructing the tissues supporting teeth, including alveolar bone resorption. ${ }^{1}$ The most common type of periodontitis is chronic periodontitis which most patients commonly do not realize because it does not cause any symptoms. However, periodontitis highly contributes in triggering potentially life-threatening systemic diseases such as atherosclerosis, myocardial infarction, stroke, rheumatoid arthritis, diabetes mellitus, and the birth of premature babies with low weight. This is caused by the toxic components of periodontitis that is easily spread to the systemic blood circulation and other body organs. ${ }^{2}$
The role of molecular immune system in periodontitis involves osteoblasts and osteoclasts. Bacterial infections trigger osteoclast to express and secret autocrine factors, such as IL-1 $\beta$. When osteoclastogenesis exceeds the osteoblast growth, it will increase bone resorption which will worsen periodontitis. Therefore, the intercellular interactions between osteoblasts and osteoclasts are very important to maintain bone homeostasis. ${ }^{3}$

Many anti-inflammatory drugs are used to treat chronic inflammatory diseases. Nonetheless, longterm use of these drugs is known to trigger gastric intestinal mucosal damage, dyspepsia, esophagitis, gastrointestinal bleeding, and perforation of the stomach, heart, and kidneys so that their use is limited. ${ }^{4}$ Therefore, it is necessary to conduct further study to find a safe drug without any adverse side effects. Herbal ingredients, such as papaya 
Majalah Kedokteran Gigi Indonesia. August 2018; 4(2): 95 - 101 ISSN 2460-0164 (print)

ISSN 2442-2576 (online)

seed which is not edible and normally wasted, is one of the alternative choices for a potential safe medication.

According to Amazu, ${ }^{5}$ papaya seeds may act as a potential antioxidant and anti-inflammatory compound by reducing the production and expression of cytokines and modulation of transcription factors. This is presumably because papaya seed extract is rich in flavonoids and phenolic acids. In line with the study of lonel et al (2015), flavonoids can reduce the degree of alveolar bone loss in ligature-induced periodontitis rats. ${ }^{6}$ Hence, this study aims to determine the role of papaya ethanol extract in inhibiting osteoclastogenesis in periodontitis rats.

\section{MATERIALS AND METHODS}

This study was designed as an experimental study classified as a post-test only control group design research type. For the experimental unit, the researcher selected 35 healthy Wistar strain male rats aged 2-3 months, weighing about 180-200 grams. The experimental rats used in the study were divided into 5 groups using the random sampling method, each with 7 rats. The first periodontitis group (P1) was induced with LPS P.gingivalis and wire ligature, and was given standard feed. The second, third and fourth periodontitis groups ( $P 2$, P3, P4) were induced by LPS P.gingivalis and ligature wire. In addition to the standard feed, these groups were also fed with the ethanol extract of papaya seeds of $200 \mathrm{mg} / \mathrm{kg} \mathrm{BW}, 300 \mathrm{mg} / \mathrm{kg} \mathrm{BW}$ and $400 \mathrm{mg} / \mathrm{kg}$ BW respectively. The control group was not induced with periodontitis and was only given standard feed. All treatments for experimental animals were approved by the Ethics Commission of the Faculty of Dentistry, Airlangga University number: 004/HRECC.FDOM/I/2017.

Rats were induced periodontitis by dropping of LPS $P$. gingivalis in the gingival sulcus in the buccal central incisor area of $5 \mu \mathrm{g}$ in $0.05 \mathrm{ml}$ PBS once a day for 7 days. This method was modified from periodontitis induction developed by Guimara es et al who injected LPS in palatal molar. ${ }^{7}$ Subsequently, on the 8th day, the induction was continued by ligature wire 0.01 . This method was modified from the study of lonel et. al using a silk ligature tied in both mandibular incisors to form an eighth figure for 7 days, which was in line with Prasetya et al. ${ }^{6,8}$ The signs of periodontitis, such as redness, swelling, gingival attachment loss, and pocket depth, were observed by the end of induction. Pocket depth was measured from free gingival margin to the pocket base and cemento enamel junction with thin wire. If the pocket was of 1-2 mm depth, it would be classified as periodontitis. ${ }^{9}$

This study used the ethanol extract of papaya seeds of Carica Papaya Linn species which was well-ripen, and blackish brown in color. The seeds were dried at a room temperature protected from direct sunlight. The seeds were then processed into extracts at the Materia Medika Batu Malang. The process was done by firstly drying the papaya seeds, grinding them into powder, weighing them each at 300 gram; dissolving them with $70 \%$ ethanol of $500 \mathrm{ml}$; putting them in a closed container, flattening them and once more adding them with $70 \%$ ethanol until they were fully submerged (the solvent used was at least 2 times the weight of the seeds or even more). The seeds were added with a solvent of $500 \mathrm{ml}$; then the jar was closed tightly for 24 hours and shaken on top of the $50 \mathrm{rpm}$ digital shaker. Afterwards, the liquid extract was filtered with a cloth filter and then stored in Erlenmeyer. The waste were put in the jar again and was added with $1000 \mathrm{ml}$ of solvent. The papaya powder mixture was fully submerged at least $5 \mathrm{~cm}$ above the surface and it was left for 12 hours while being shaken. Re-maceration was carried out using $1000 \mathrm{ml}$ of solvent until the filtrate/ extract was clearer. The results of the first to the last liquid extract were mixed and evaporated using a rotary evaporator for 4 hours. The extract produced was evaporated on a water bath for 2 hours. 300 grams of papaya seed powder extracted using $70 \%$ of ethanol solven of $3 \mathrm{~L}$ produced $100 \mathrm{ml}$ extracts. Extracts were fed to P2, P3, and P4 groups for 15 days orally using a sonde, starting on the 15th day, once a day at 08.00 - 09.00 of Indonesian Western Standard Time. Extracts of $50 \mathrm{mg}$ were dissolved in distilled water to obtain $100 \mathrm{ml}$ of extract with 0.5 concentration gram. 
After administration of papaya seed extract for 15 days, rats were killed. Their mandibular bone was separated from their soft tissue and fixed with $10 \%$ formalin buffer solution to make paraffin block preparations. The tissue was decalcified with $10 \%$ EDTA liquid for 30 days at room temperature and the liquid was replaced every day. In the following stage, the area near the gingival sulcus was cut at approximately 2-3 $\mathrm{mm}$ thick, to be processed by an automatic tissue tex processor for 90 minutes. Then, the tissue was embedded with paraffin according to the network code and cut with microtome tools of 3-5 microns thick.

Afterwards, tissue preparations were placed in the oven for 30 minutes at a temperature of $70-80{ }^{\circ} \mathrm{C}$. Then, they were put into a tube of xylol solution for 20 minutes, tube alcohol for 3 minutes (hydration), and they were finally washed with running water. In the subsequent stage, the preparations were stained with hematoxylin and then washed with running water, $1 \%$ acidic alcohol, and water ammonia. Next, the preparation was stained with $1 \%$ eosin and washed with $80 \%$ alco- hol, $96 \%$ alcohol, $96 \%$ alcohol, and purified with $x y-$ lol. Finally, the preparations was mounted with an Entellan and covered with glass.

Osteoclasts in this study were identified as cells with many nuclei and were in direct contact with the bone surface, having pale and foamy cytoplasm and irregular core shapes. The number of osteoclasts in the alveolar bone, trabecular bone and periodontal area was obtained by counting all the cells observed in the entire field of view at 1000x magnification. This examination used a Nikon H600L light microscope equipped with a 300 megapixel Fi2 DS digital camera and Nikkon Image System image processing software. Data were analyzed using IBM SPSS Statistics 19 using analysis of variance (ANOVA).

\section{RESULTS}

The highest number of osteoclasts was found in group P1, which was equal to 3.42 , subsequently followed by P2 with 3, P3 with 1.57 and sharply decreasing to P4 with 0.57 . Data normality and homogeneity test showed the normal and homo-

Table 1. Average and standard deviation of osteoclast $d$ in each group

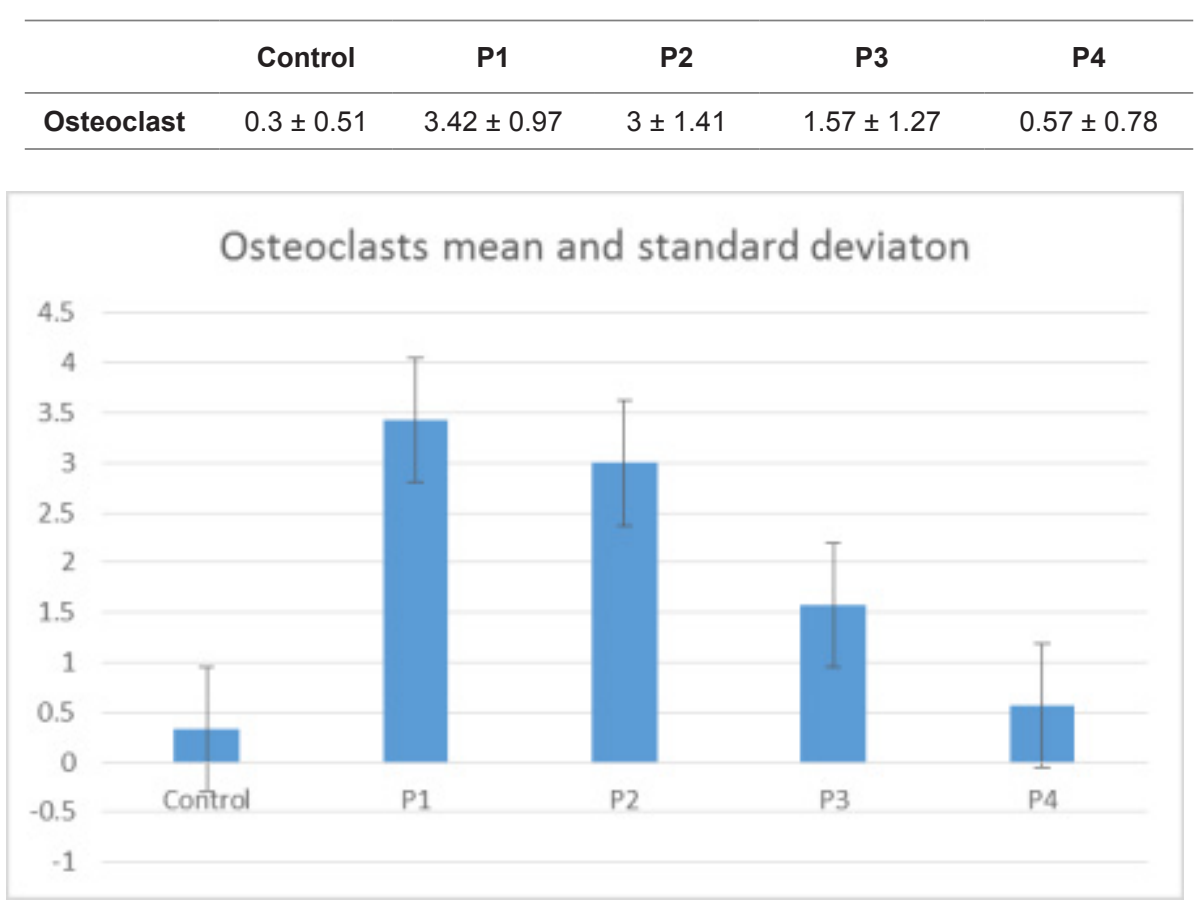

Figure 1. Osteoclast mean and standard deviation in each group, Control group: without induction of periodontitis, P1: group of periodontitis without administration of extract, P2: periodontitis group with extract dose of $200 \mathrm{mg} / \mathrm{kg} \mathrm{BW}$, P3: periodontitis group with extract dose of $300 \mathrm{mg} / \mathrm{kg} \mathrm{BW}$, and P4: periodontitis group with extract dose of $400 \mathrm{mg} / \mathrm{kg} \mathrm{BW}$ ). 
Majalah Kedokteran Gigi Indonesia. August 2018; 4(2): 95 - 101

ISSN 2460-0164 (print)

ISSN 2442-2576 (online)

Table 2. Different tests using ANOVA showed significant differences $(p<0.05)$

\begin{tabular}{llllll}
\hline Average number of osteoclasts & Sum of Squares & Df & Mean Square & F & Sig. \\
\hline & 52.465 & 4 & 13.116 & 11.712 & .000 \\
\hline Between Groups & 32.476 & 29 & 1.120 & & \\
Within Groups & 84.941 & 33 & & & \\
Total & & &
\end{tabular}
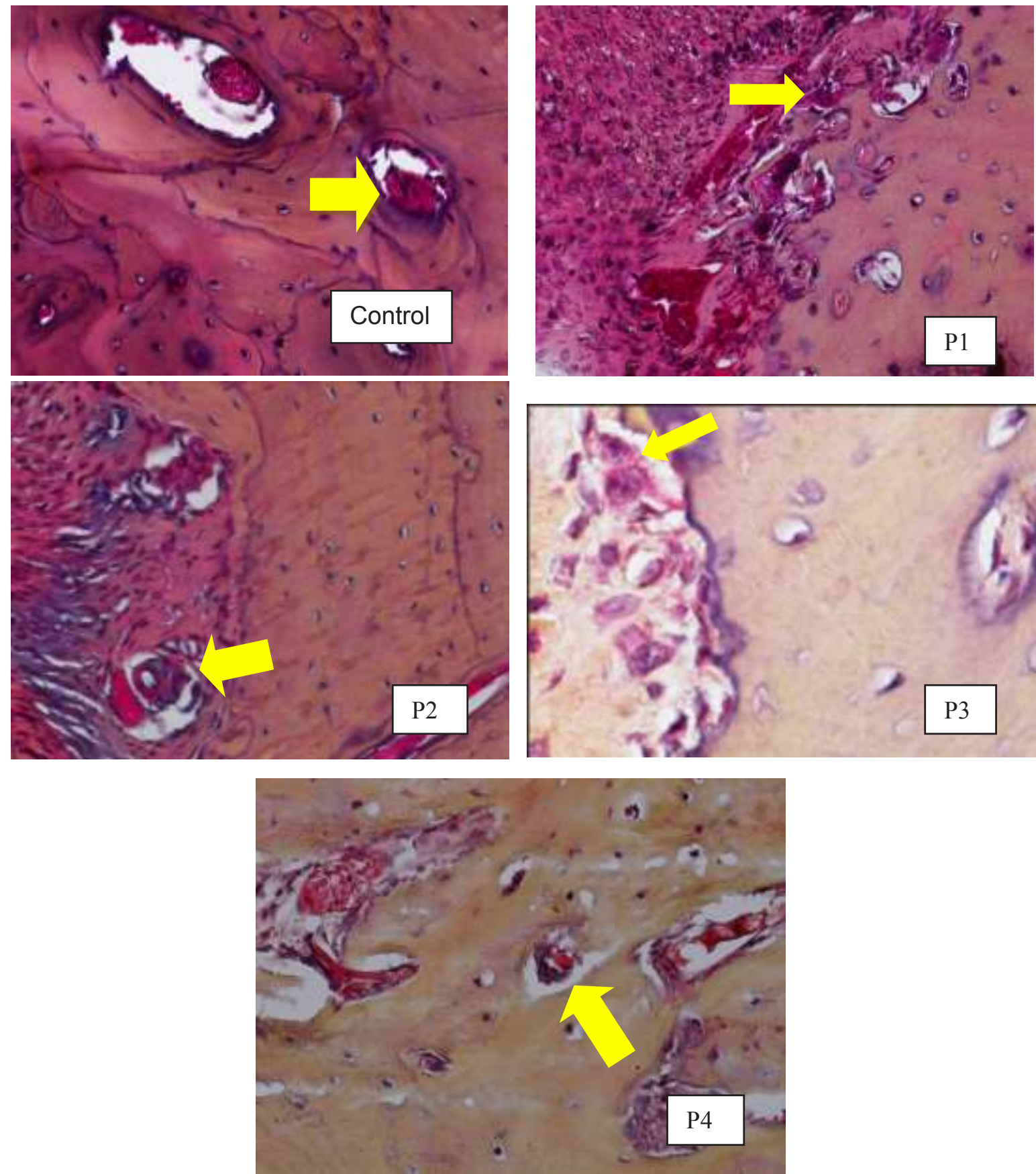

Figure 2. Osteoclast picture of Hematoxilin eosin stain (yellow arrow), Changes of osteoclast number in group, Control: without induction of periodontitis, P1: group of periodontitis without administration of extract, P2: periodontitis group with extract dose of $200 \mathrm{mg} / \mathrm{kg} \mathrm{BW}, \mathrm{P} 3$ : periodontitis group with extract dose of $300 \mathrm{mg} / \mathrm{kg} \mathrm{BW}$, and P4: periodontitis group with extract dose of $400 \mathrm{mg} / \mathrm{kg} \mathrm{BW}$ ). 
geneous distribution data, so that the parametric ANOVA test was carried out. The ANOVA test revealed a significant difference in the average decrease of osteoclast in each treatment group. The average osteoclast data in periodontal tissues of rats is presented in Table 1.

\section{DISCUSSION}

In this study the LPS was not injection but it was done by expelling a liquid drop on the gingival sulcus. In this way, it was expected that the inflammation was purely caused by the interaction of LPS bacteria with gingival tissue. The LPS induction of P. gingivalis until the 7th day only showed a clinical picture of gingivitis. Thus, the induction was continued with ligature wiring which was modified based on the study of lonel et al (2015) using silk ligature. ${ }^{6}$

Gram negative bacteria containing LPS is noted to cause inflammation by inducing local responses to periodontal tissue, characterized by infiltration of polymorphonuclear leukocytes, production of reactive oxygen species (ROS), and inflammatory mediators such as cytokines and prostaglandins, amplification of lytic enzymes, osteoclast activation, edema, and dilation of blood vessels. ${ }^{10}$ Inflammation was followed by resorption of alveolar bone and the emergence of osteoclasts on the alveolar bone surface. ${ }^{11}$ Silk ligature was a factor in the retention of plaque bacteria that caused periodontitis. Bacterial stimulation triggered a host response followed by infiltration of inflammatory cells, osteoclast formation, bone loss and loss of tooth attachment. ${ }^{6}$

On the basis of this study, it can be seen that the number of osteoclasts in the group with an extract dose of $400 \mathrm{mg} / \mathrm{kg}$ BW decreased sharply as seen from the comparison between each dose of ethanol extract of papaya seeds. This is in line with what was revealed by Dudarić (2015) that polyphenols can reduce inflammatory mediators such as differentiation and activity of osteoclast. These include mechanisms for bone formation by inhibiting osteoclastogenesis, reducing osteoclast activity (blocking the production of RANKL), and decreasing the production of pro-inflammatory factors such as COX-2. ${ }^{12}$
The results of this study indicate that a dose of $400 \mathrm{mg} / \mathrm{kg}$ BW had the greatest effect in decreasing osteoclasts, approaching osteoclast number of the non-periodontitis-induced control group. This result is in contrast to the research by Amazu et al. (2010) which stated that at a dose of $200 \mathrm{mg} / \mathrm{kg}$ BW papaya seed extract had a considerable anti-inflammatory effect on the edema of the feet of rats and measured its diameter. ${ }^{5}$ This was probably caused by a periodontitis chronic inflammation, which is a prolonged inflammatory process that involves tissue and bone damage. ${ }^{13}$ Therefore, a larger dose of extract is needed to inhibit the chronic inflammation.

This study used ethanol extract of papaya seeds by referring to phytochemical qualitative analysis of Materia Medika Batu Malang denouncing that they contained polyphenol compounds in the form of phenolic acids and flavonoids. Polyphenols are known to be potential antioxidants having the ability to influence the work of cytokines in the inflammatory response. ${ }^{14}$ The results of this study are also in line with Kumar et al (2009) highlighting that plant bioactive compounds such as phenolic acid and flavonoids significantly help cure periodontitis since it potentially act as antiinflammation. ${ }^{15}$

However, the exact dose of polyphenols to cause therapeutic effects on periodontitis is still unclear. Therefore, this study referred to Amazu et al. (2010) which stated that papaya seed extract at a dose of $200 \mathrm{mg} / \mathrm{kg}$ gave an anti-inflammatory effect in rat experiments. This study used three different doses to determine whether these doses affected the osteoclast mean. Oral administration of papaya seed extract for 15 days starting on the 15 th day after the completion of periodontitis induction, by referring to the study conducted by Köse et al. ${ }^{9}$

The anti-inflammatory potential of ethanol extract of papaya seeds which works by way of inhibiting osteoclastogenesis is the focal point of this study. As is known, the inflammatory process that triggers osteoclastogenesis and resorption of bone is also responsible for the failure of new bone formation in adequate amounts. The amount of bone loss that occurs in periodontitis is caused by 
the accumulative effect of inflammation that triggers resorption, and unbalance between bone resorption and new bone formation. ${ }^{14,16}$

The only drawback of the study is that the content of phenolic acid and flavonoids of papaya seeds ethanol extract in this study were not in the form of pure isolates and that the actual percentage of the active compounds of phenolic acids and flavonoids in these papaya extracts remained unknown. ${ }^{17}$

\section{CONCLUSION}

On the basis of the study, it was concluded that the ethanol extract of papaya seeds had a pivotal role in the healing process of periodontal tissues of periodontitis rats, so that it has the potential as an anti-inflammatory material. The higher the extract dose given, the lower the number of osteoclasts.

However, this study has not revealed the actual percentage of the active compounds of phenolic and flavonoid acids in the ethanol extract of papaya seeds. Therefore, the proposed mechanism of action is only a conjecture. There are other possible factors that contribute in inhibiting osteoclatogenesis in rats with periodontitis, so further research is still needed on the ethanol extract of papaya seeds.

\section{REFERENCES}

1. Silva N, Abusleme L, Bravo D, Dutzan N, Garcia-Sesnich J, Vernal R, Hernandez M, Gamonal J. Host response mechanisms in periodontal diseases. J Appl Oral Sci. 2015; 23(3): 329-355. doi: 10.1590/1678-775720140259.

2. Kamer AR, Craig RG. A clinician's guide to systemic effects of periodontal diseases. 2016. 93-106. Available from: http://link.springer. com/10.1007/978-3-662-49699-2.

3. Hienz SA, Paliwal S, Ivanovski S. Mechanisms of bone resorption in periodontitis. J Immunol Res. 2015; 2015: 615486. doi: 10.1155/2015/615486

4. Leyva-Lopez N, Gutierrez-Grijalva EP, Ambriz-Perez DL, Heredia JB. Flavonoids as cytokine modulators: A possible therapy for inflammation-related diseases. Int J Mol Sci. 2016;17(6). doi: 10.3390/ijms17060921.
5. Amazu LU, Azikiwe CCA, Njoku CJ, Osuala FN, Nwosu PJC, Ajugwo AO, Enye JC. Antiinflammatory activity of the methanolic extract of the seeds of Carica papaya in experimental animals. Asian Pac J Trop Med. 2010; 3(11):884-886.

doi: 10.1016/S1995-7645(10)60212-X.

6. Ionel A, Lucaciu O, Moga M, Buhatel D, llea A, Tabaran F, Catoi C, Berce C, Toader S, Campian RS. Periodontal disease induced in Wistar rats - experimental study. HVM Bioflux. 2015; 7(2): 90-95.

7. Guimarães MR, De Aquino SG, Coimbra LS, Spolidorio LC, Kirkwood KL, Rossa C. Curcumin modulates the immune response associated with LPS-induced periodontal disease in rats. Innate Immun. 2012; 18(1): 155-163. doi: 10.1177/1753425910392935.

8. Prasetya RC, Purwanti N, Haniastuti T. Infiltrasi neutrofil pada tikus dengan periodontitis setelah pemberian ekstrak etanolik kulit manggis. Majalah Kedokteran Gigi Indonesia. 2014; 21(1): 33-38.

9. Köse O, Arabaci T, Kizildag A, Erdemci B, Özkal ED, Gedikli S, Özkanlar S, Zihni M, Albayrak M, Kara A, Kermen E. Melatonin prevents radiation-induced oxidative stress and periodontal tissue breakdown in irradiated rats with experimental periodontitis. J Periodontal Res. 2017; 52(3): 438-446. doi: 10.1111/jre.12409

10. Kostić M, Kitić D, Petrović MB, JevtovićStoimenov T, Jović M, Petrović A, Živanović S. Anti-inflammatory effect of the Salvia sclarea L. ethanolic extract on lipopolysaccharide-induced periodontitis in rats. J Ethnopharmacol. 2017; 199: 52-59. doi: 10.1016/j.jep.2017.01.020.

11. Rajendrasozhan S, Yang S-R, Edirisinghe I, Yao H, Adenuga D, Rahman I. Deacetylases and NF- $\mathrm{K} B$ in Redox Regulation of Cigarette Smoke-Induced Lung Inflammation: Epigenetics in Pathogenesis of COPD. Antioxid Redox Signal. 2008; 10(4):799-812. doi: 10.1089/ars.2007.1938. 
12. Dudarić L, Fužinac-Smojver A, Muhvić D, Giacometti J. The role of polyphenols on bone metabolism in osteoporosis. 2015; 77(2): 290-298. doi: 10.1016/j.foodres.2015.10.017.

13. Benso B, Franchin M, Massarioli AP, Paschoal JAR, Alencar SM, Franco GCN, Rosalen PL. Anti-inflammatory, anti-osteoclastogenic and antioxidant effects of malva sylvestris extract and fractions: In vitro and in vivo studies. PLoS One. 2016; 11(9): 1-19.

doi: 10.1371 journal.pone. 0162728.

14. Trzeciakiewicz A, Habauzit V, Horcajada MN. When nutrition interacts with osteoblast function: Molecular mechanisms of polyphenols. Nutr Res Rev. 2009; 22(1): 68-81. doi: 10.1017/S095442240926402X.
15. Kumar P, Ansari SH, Ali J. Herbal remedies for the treatment of periodontal disease - a patent review. Recent Pat Drug Deliv Formul. 2009; 3(3): 221-228. doi: 10.2174/187221109789105603.

16. Maruyama $\mathrm{T}$, Tomofuji $\mathrm{T}$, Endo $\mathrm{Y}$, Irie $\mathrm{K}$, Azuma T, Ekuni D, Tamaki N, Yamamoto T, Morita Met. Supplementation of green tea catechins in dentifrices suppresses gingival oxidative stress and periodontal inflammation. Arch Oral Biol. 2011; 56(1): 48-53. doi: 10.1016/j.archoralbio.2010.08.015.

17. Subhashini R, Mahadeva Rao U, Sumathi P, Gunalan G. A comparative phytochemical analysis of cocoa and green tea. 2010; 3(2): 188-192. 